\title{
Unmasking, Exposing, and Confronting: Critical Race Theory, Tribal Critical Race Theory and Multicultural Education
}

\author{
Jeanette Haynes Writer \\ New Mexico State University \\ U. S. A.
}

Critical Race Theory (CRT) and Tribal Critical Race Theory (TribalCrit) offer the possibility of unmasking, exposing, and confronting continued colonization within educational contexts and societal structures, thus transforming those contexts and structures for Indigenous Peoples. Utilizing CRT and TribalCrit to support and inform "multicultural education as social justice," we rid ourselves, our educational institutions, and ultimately the larger society from the "food, fun, festivals, and foolishness" form of multicultural education that maintains or propagates colonization.

Introduction

The Offering of Critical Race Theory and Tribal Critical Race Theory

Multicultural Education and Social Justice

The Historical Context of Education in the U.S.

Decolonization in Schooling and Teacher Preparation

Conclusion

Notes

References

\section{Introduction}

In April 2008 I presented at the second annual Native American and Indigenous Studies Conference in Athens, Georgia. This was a gathering of Indigenous ${ }^{\underline{1}}$ scholars and non-Indigenous allies who teach within Indigenous Studies programs, who teach Indigenous-focused courses or who concentrate on Indigenous issues within the scope of their research. Scholars from throughout the Americas, Canada, Australia, and New Zealand came together to present and dialogue on historical and contemporary issues and to network and coalesce. Within a few presentations my attention was drawn to the way some spoke about or alluded to multicultural education (MCE) and multiculturalism in negative ways-connecting it to the continued process of colonization. As an Indigenous person, specifically Tsalagi (Cherokee Nation of Oklahoma) and associate professor who primarily teaches the undergraduate and graduate MCE course within a teacher education program, this was very problematic to me and reminds me of the work we must do in MCE to advance the movement toward "MCE as social justice," to rid ourselves, our educational institutions, and ultimately the larger society from the "food, fun, festivals, and foolishness" form of MCE that maintains or propagates colonization. 
Sahnish and Hidatasa scholar, Michael Yellow Bird (2005) speaks to the colonization manifested within our educational institutions:

The U.S. educational system has been one of the most hostile and oppressive aspects of colonialism....Colonized-based educational systems contributed significantly to the destruction of cultural knowledge, and the imposition of the belief that Indigenous Peoples and their knowledge and ideas were-and remain-less than those of mainstream peoples. (p. 16)

Although Yellow Bird's criticism addresses U.S. educational systems specifically, it is descriptive of the colonization exerted through educational systems for Indigenous Peoples elsewhere.

The negativity towards multicultural education and multiculturalism at the conference was accompanied by comments regarding the inclusion of Indigenous Peoples in educational contexts or content-if inclusion is not being done by us or from our frame of reference, leave Indigenous Peoples out of the discourse and curriculum content; otherwise, colonization and oppression are perpetuated. That is, the information regarding Indigenous people must come from what we have to say about ourselves, through our stories and perspectives. As a Native person, I concur with this sentiment.

In this article I argue that Critical Race Theory (CRT) and Tribal Critical Race Theory (TribalCrit) offer the possibility of unmasking, exposing, and confronting continued colonization within educational contexts and societal structures, thus transforming those contexts and structures for Indigenous Peoples. CRT and TribalCrit may be useful alongside, or in support of, traditional

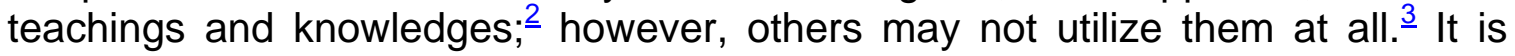
important to provide a note of caution here. Although the term "Indigenous" is used, it entails hundreds of distinct groups. I do not assume that CRT and TribalCrit will work for all or be appropriate for all; that is why I use the term "offer."

Following an overview of the history and discussion of CRT and TribalCrit, I present a brief history and a definition of MCE and provide a discussion of social justice, positioning MCE as social justice. Then, after a brief historical overview and continued example of colonization specific to the U.S. Indigenous Peoples, I contend that by utilizing MCE as social justice in our teacher education programs and schools, colonization can be challenged and disrupted.

\section{The Offering of Critical Race Theory and Tribal Critical Race Theory}

In the mid-1970s, Critical Race Theory (CRT) developed in the United States out of Critical Legal Studies to examine the relationship between race, racism, and power. A basic assumption is that racism is not merely individual acts of discrimination, but rather historical, systemic, and ideological manifestations of power to serve, maintain, and protect white privilege (Delgado, 
1989; Harris, 1993). CRT includes an activist dimension along with this examination to facilitate transformation (Delgado \& Stefancic, 2001).

The goal of CRT is to construct an alternative reality by naming one's reality through storytelling and counterstorytelling; thus, the advantage of CRT is the voice that it provides people of color. Examples of "voice" include "parables, chronicles, stories, counterstories, poetry, fiction, and revisionist histories" (Ladson-Billings \& Tate, 1995, p. 57). CRT allows for the contestation, deconstruction, and reshaping of the master narrative by enlisting multiple perspectives and experiences as sources of valid knowledge which serve as catalysts for transformation. For members of the dominating society, CRT provokes a "cognitive conflict to jar white dysconscious racism" (Ladson-Billings, 1998 , p. 16), disrupting particular beliefs about the world. CRT then provides crucial knowledge to white people because it helps them "grasp what it is like to be nonwhite" (Delgado \& Stefancic, 2001, p. 39); that is, counterstorytelling serves to "help us understand what life is like for others and invite the reader into a new and unfamiliar world" (p. 41).

Indigenous scholars (Brayboy, 2005; Haynes Writer, 2002b, 2008; Hermes, 1999; Rains, 2003; Williams, 1997) began employing CRT to examine the effects of race, racism, and power in our communities and on ourselves and utilized CRT as a mechanism to perform truth-telling-to speak back to colonization and oppression. Lumbee scholar Bryan Brayboy (2005) introduced Tribal Critical Race Theory (TribalCrit) to examine the issues of Indigenous People in relationship to the United States and its laws and policies. Although a significant role is played by racism, a primary tenet within TribalCrit is the endemic nature of colonization and its processes in society. TribalCrit functions to "expose the inconsistencies in structural systems and institutions...[to] make the situation better for Indigenous students" (p. 441).

CRT and TribalCrit generate truths about colonization in larger social and structural contexts, facilitating change. "Since the truth about injustices perpetuated against Indigenous People has been largely denied in the United States, truth-telling becomes an important strategy for decolonization" (Wilson \& Yellow Bird, 2005, p. 7). Thus, I offer and advocate for CRT and TribalCrit as ontological and epistemological frameworks to construct MCE as social justice; to function as a means to access and understand the "story" of colonization of Indigenous Peoples; to understand how colonization is continually enacted upon Indigenous Peoples; and to change that enactment of colonization.

\section{Multicultural Education and Social Justice}

\section{Multicultural Education}

MCE originated in the United States out of the Civil Rights movement in the late 1960 s as various ethnic groups challenged and confronted 
unconscionable oppressions and inequities enacted upon them historically and continued through individual, institutional, and structural discrimination. Women, people with disabilities, and gays and lesbians followed, demanding equality and equity in representation, treatment, and opportunity. Since that time MCE has spread beyond the United States to become an international movement. However, according to May (1999), as the MCE movement spread, it "promised much and delivered little" (p. 1) because it was often presented and practiced superficially.

Former tribal college president and Crow Nation citizen Janine PeaseWindy Boy (1995) addressed the superficiality of MCE inclusion, "All too often, the mainstream educational institutions regard cultural diversity as a few learning units that are cosmetically brown or black in complexion or as a few festivals that celebrate the food, clothing, or dance of minorities" (p. 399). It is from this superficiality, this "food, fun, festivals, and foolishness," that the Indigenous critique of inclusion emanates. May (1999) specifically speaks to the failure within multicultural debates to acknowledge the voices and concerns of Indigenous Peoples.

MCE may be thought of as a continuum; on one end is the superficial form, and on the other end is MCE as social justice. The superficial form adds a unit on minorities or "Others" here and there, maintaining and supporting the privilege of the dominating society. This follows Critical Race Theorist and legal scholar Derrick Bell's (1980) concept of "interest convergence," where the material interests of whites ${ }^{4}$ are maintained while giving some attention to minority presence and meeting their psychic interests. The MCE as social justice approach disrupts privilege by mediating and redistributing power and resources, identifying and utilizing various forms and sources of knowledge, confronting oppression, and examining the intersectionalities of the various forms of diversity within oppression.

Although a significant amount of literature has been developed in the field of MCE, scholars have not settled on one specific definition due to the MCE continuum. In my MCE courses, I draw upon the MCE definition of Sonia Nieto and Patty Bode (2008). Within their comprehensive definition, Nieto and Bode demarcate it as a process of comprehensive school reform, challenging and rejecting racism and other forms of oppression, not only within the schools but with extension into society. MCE is described as affecting and transforming curriculum, instructional strategies, conceptualizations of teaching and learning, and interactions among stakeholders within the schooling process. Along with this description, Nieto and Bode (2008) identify seven key characteristics. MCE is basic education, important for all students, pervasive, a process, antiracist education, education for social justice, and critical pedagogy.

Critical pedagogy is a vital component of MCE because it involves the teaching of critical analysis. It "links knowledge of diversity and inequality with actions that can make the culture more socially just" (Oakes \& Lipton, 2007, p. 100). It is this critical awareness, analysis, and action that institutes transformation: "Because [MCE] uses critical pedagogy as its underlying 
philosophy and focuses on knowledge, reflection, and action (praxis) as the basis for social change, multicultural education furthers the democratic principles of social justice" (Nieto \& Bode, 2008, p. 44).

\section{Social Justice}

In the words of Lee Anne Bell (1997),

Social justice includes a vision of society in which the distribution of resources is equitable and all members are physically and psychologically safe and secure....in which individuals are both self determining (able to develop their full capacities), and interdependent (capable of interacting democratically with others)... [it] involves social actors who have a sense of their own agency as well as a sense of social responsibility toward and with others and the society as a whole. (p. 3)

It is this social justice definition that works to the advantage of Indigenous Peoples; it is here that the disruption of colonization can occur. As both process and a goal, social justice advances the interrogation of the manifestations of power and the dynamics of oppression, such as in the distribution of resources that individuals have access to and the experiences that individuals and groups have due to their privileged or non-privileged status. From this interrogation, a plan of action is developed to transform systems of oppression. Social justice requires the study of historical issues and events to understand the manifestations of oppression in its present form.

Whereas MCE, as discussed above, is usually situated within schools and educational contexts, social justice moves it out further, driving the disruption and confrontation of oppression and requiring transformation in larger sociopolitical contexts. It is here that the state of affairs of Indigenous Peoples is affected. MCE as social justice, informed and supported by CRT and TribalCrit, serves as a catalyst to access multiple perspectives, propelling us toward systemic transformation, thus decolonization.

Although this article involves MCE for Indigenous Peoples, I must now shift to a concentration of the history of Native people within the United States to further discuss the offering of these frameworks. In the next section I present a much abbreviated overview of the history of colonization of the Native people within the 48 contiguous states to illustrate that the issues of the past are very much with us in the present. In doing this, I present a specific example of the protection and advancement of white privilege, which serves as evidence of the continuance of colonization. 


\section{The Historical Context of Education in the United States}

Porter (2005) defines colonization as "the process by which a people exploit and/or annex the lands and resources of another without their consent and unilaterally expand political power over them" (p. 108). Colonization was enacted as Europeans immigrated to this continent and kept arriving, imposing a "civilized" presence against that of an Indigenous presence-the "savage" Other. Native Peoples were viewed as obstacles to civilization and "progress." Native Peoples' occupancy of land was not appropriate according to European standards - they had use of too much of it and were not improving it-which justified the separation of them from the land. As Europeans, and then European Americans, encroached further and further, it became imperative to condemn Indigenous People to the realm of the Other; they were constructed as "less than" and expendable. Native Americans had to be dealt with. Options included: genocide (Mohawk, 2000; Stannard, 1992; Stiffarm \& Lane, 1992; Thornton, 1987); removal to westward territories and later reservations (Kvasnicka \& Viola, 1979; Prucha, 2000); and forced assimilation through civilizing methodologies (Adams, 1995; Archuleta, Child, \& Lomawaima, 2000; Hoxie, 1984; Prucha, 2000; Spring, 1996; Trafzer, Keller \& Sisquoc, 2006). As colonization was inflicted upon Native Peoples, the assertion of cultural imperialism in conjunction with colonization laid the foundation for assimilation and cultural genocide. To experience cultural imperialism, Young (2000) explains, is “...to experience how the dominant meanings of a society render the particular perspective of one's own group invisible at the same time as they stereotype one's group and mark it as Other" (p. 44). Within cultural imperialism, the dominating group's experience is elevated, sanctioned, and universalized; it becomes the norm that all others are obligated to accommodate.

Westernized education advanced the agenda of the "superior" European Americans. As such, education cleared the path to creating a mythical state of harmony between Native Americans and whites, but it was the whites who were accommodated in the process. Native People were fashioned into farmers of small acreages as a means to divest them from larger territories. Traditional homelands became "owned" by whites and eventually exploited of natural resources. Native Americans were fashioned into laborers, becoming the profit margin of whites within a larger, capitalist economy. Native Peoples' languages, representing their worlds, complex knowledges, and spiritual centers, were stripped from them and replaced with the English language, utilized as tools to oppress, silence, and standardize (Adams, 1995; Spack, 2002). Schools served Christian interests, manifesting their ideologies and philosophies not only to legitimize white Christian privilege, but to reproduce it at the expense of the colonized Native People-traditional ceremonies were labeled as pagan and outlawed. Westernized schools and Christianity worked hand-in-hand to reconfigure Native families, thus stripping Indigenous women from places of authority, honor, and reverence in families and communities (Archuleta, Child, \& Lomawaima, 2000; Lomawaima, 1994; Perdue, 2001). Children were kidnapped 
and placed into boarding schools where they were mentally, physically, and sexually abused. Native Peoples became objects of curiosity, show pieces in Wild West Shows and World Fairs. They became subjects of study and examination by academics. Their status as sovereign people was constructed legally and socially into a colonized Other; they became child-like wards under the authority of a paternalistic government. Colonization was an allencompassing project.

As Wilson and Yellow Bird (2005) make clear, "The current institutions and systems are designed to maintain the privilege of the colonizer and the subjugation of the colonized, and to produce generations of people who will never question their position within this relationship" (p. 1). A recent example of the maintenance of white privilege and exertion of colonization is Arizona Senate Bill 1108. This legislation was proposed in the Arizona House of Representatives in April 2008 by Republican Representative Russell Pearce to abolish the Movimiento Estudiantil Chicano de Aztlan (MEChA) and Mexican-American study programs; however, Indigenous students, teachers and faculty are directly affected in the fallout. Pearce's $s^{-\frac{5}{}}$ proposed legislation demands the following:

A public school in this state shall not include within the program of instruction any courses, classes or school sponsored activities that promote, assert as truth or feature as an exclusive focus any political, religious, ideological or cultural beliefs or values that denigrate, disparage or overtly encourage dissent from the values of American democracy and western civilization, including democracy, capitalism, pluralism and religious toleration. (Arizona State Legislature, 2008)

The bill stipulates that public tax dollars shall not be used in the "denigration" of American values or Western civilization (read: "censorship") and mandates the State Superintendent of Public Instruction to confiscate books and teaching materials that are deemed anti-American. Additionally, public schools, community colleges, and universities may not permit organizations which are "based in whole or in part on race-based criteria," such as an American Indian Student Association. However, organizations based on gender, religion, and political affiliations (i.e. Young Republicans) shall be permitted.

At issue is who has the power to claim the title "American," which is encoded as white. "American = white" implies that "American values" may be defined along lines of interest which supports whiteness as property. Although the final outcome of this legislation is unknown at the time of this writing, the bill was passed April 16, 2008, by the State House Appropriations Committee and advanced to the full House and Senate for a vote. Regardless of outcome, the introduction of such legislation serves as both evidence and enactment of white privilege and whiteness as property, where whiteness and its encompassing history are normalized. In the process colonization is supported, propagated and legislated. Divergent voices, including those of Native people's truth-telling of our history and experiences, are silenced and essentially outlawed. We must ask the questions: How does this happen? Why is this permitted? 


\section{Decolonization in Schooling and Teacher Preparation}

In her keynote at the 2003 American Indian Studies Consortium, Wilma Mankiller, former Principal Chief of the Cherokee Nation, spoke of protecting Indigenous sovereignty and self-determination because most Americans know little about Native Americans. Instead, they believe stereotypes, such as that Native people are innocent children of nature, not capable of higher thought, and that all Native people receive government checks and spend their time at casinos. These beliefs are rooted in a history of Othering and colonization. Mankiller stressed that stereotypes and historical inaccuracies transmitted in public schools threaten sovereignty because "public perceptions fuel public policy" (Mankiller, 2003). That is, students eventually become voters and vote according to their beliefs about Indigenous People, approving legislation that affects Indigenous People-as in the example of Arizona House Bill 1108. Belief becomes practice. Reading through a CRT and TribalCrit lens, I add to Mankiller's statement and say that public perceptions also fuel public practice. To grasp this connection, we need only to examine the colonizing and assimilating events, policies, and processes mentioned above. The connection of public perception to public practice is clear. Whereas European Americans, under the auspices of the colonial and then U.S. federal government, legislated particulars of domination, it was the collusion of members of the public with the government that those legislated oppressions were carried out. Public perception translated into public practice, thus transforming Native people into objects of subjugation.

Due to the lack of attention within teacher preparation programs to Indigenous communities, silences, inaccuracies, and stereotypes flourish, which damages us all. The careful preparation of pre-service and in-service teachers within a MCE as social justice framework promises to extend a deepened and socially just education to students (Haynes Writer, 2002a; Pewewardy, 1999), and ultimately our citizenry. Teachers in the field must be challenged within their professional development to teach appropriate and accurate representations of Indigenous Peoples. The ripples from this have potential to eventually affect public policy and public practice.

The opportunity for teachers to disrupt continued colonization and dominance can be illustrated using the example of the Oklahoma Centennial. In November, 2007, the state of Oklahoma "celebrated" its $100^{\text {th }}$ anniversary of statehood. However, events leading to and following statehood were devastating for the state's 39 tribal nations. Costs to tribal nations included the invasion of tribal lands by non-Natives; the confiscation of millions of acres of communal tribal lands through the Dawes Act and redistribution through individual allotments; the opening of remaining tribal lands and "unassigned lands" to nonNatives through land runs and lotteries; the denial of the State of Sequoyah by President Theodore Roosevelt; upon statehood, the dissolution of tribal governments,,$\frac{6}{}$ the elimination of tribal courts and schools, and the takeover of tribal funds, buildings, and property by the State; the graft, exploitation, and 
death resulting from the greed over land and mineral resources; and the blatant poverty, illiteracy, and racism experienced by Indigenous Oklahomans. Respected Historian Angie Debo maintained that, "The plunder of Indians was so closely joined with pride in creation of a great new commonwealth that it received little condemnation" (1940/1991, p. 92).

Along with voicing concerns regarding economic challenges to tribal communities and individuals, the assault of English Only legislation on Native languages, and racism within the state, Centennial demonstrators, tribal leaders, and other tribal members voiced their concerns about misrepresentations and historical inaccuracies in the public school curriculum. For example, the Oklahoma Council for the Social Studies (n.d.) has on its website a detailed lesson titled, We're Off To The Land Run!: What Do We Need To Take Along? The lesson claims an educational value of having $3^{\text {rd }}-5^{\text {th }}$ grade students "apply economic concepts" as they plan to participate in a land run. I assert that students are inculcated with a lesson on the invisibility of Native people. Nowhere in the two page, single-spaced lesson is any mention made of the impact of the land runs on tribal nations or Native People in general. The lesson instructs teachers to first discuss the land run with students, asserting that the land was "the last large parcel of land in the United States to be given away by the Federal government"; however, teachers are not instructed to discuss with students the confiscation of the land from tribes. As such, land run re-enactments remain points of contention for Indigenous Oklahomans. Brenda Golden, Creek tribal member and an organizer of the Oklahoma Indian Survival Walk and Remembrance Ceremony held on statehood day, remarked of the schools' land run re-enactments, "I just tell my children go sit in the middle of the lawn and let the kids run over you because that's what happened to us" (McNutt, 2007, ๆ. 10).

Utilizing MCE as social justice, the teaching of Oklahoma history can be reframed, as teachers and students research the above costs of statehood by accessing tribal histories, historical documents, and visual (i.e. news coverage and artwork produced by Native artists), printed, and oral perspectives of statehood and the Centennial by Indigenous Oklahomans. Using our historical and contemporary words, stories, and frames of reference helps students make connections to oppressions and inequalities that exist for Native people today. This in turn has the potential to transform public perception, policy, and practice, thus disrupting colonization. Utilizing MCE and social justice, supported and informed by CRT and TribalCrit, educators, with their students, can critically examine historical decisions of the past and consider what it means to be Indigenous Peoples within states and larger nations of occupation.

Solorzano and Yosso (2002) state that "although race and racism are at the center of a critical race analysis, we also view them at their intersection with other forms of subordination such as gender and class discrimination" (p. 25). Thus CRT and TribalCrit are useful tools in telling the stories of historical and contemporary issues affecting Indigenous Peoples among those complex intersections. This facilitates the examination of whiteness as property, which interrogates white privilege and dislocates the normativity of whiteness. 
Colonization is disrupted, allowing for the reclaiming and re-centering of Indigenous knowledges, experiences, and perspectives.

Whereas this is in no way a comprehensive list, here are some issues that are at the forefront of concern for Indigenous Peoples: Native feminisms, sexual violence against Indigenous women, boarding school abuses, environmental issues and contamination, Indigenous identity, language destruction and revitalization, research issues and ethics in Indigenous communities, Indigenous representations and stereotypes, Indigenous perspectives of historical events, [de]colonization, sovereignty and self-determination, religious freedom and repatriation, Indigenous education, and Indigenous knowledge and intellectualism. I encourage the reader to investigate others.

\section{Conclusion}

Indigenous Peoples must be removed from the collective "minority" status in the general public discourse and moved to the reality of being members of culturally and politically sovereign nations. As well, we must also be removed from artifacts of the historical past, to actors in a transformative present. Indigenous Peoples around the world have challenged colonization and the imposition of whiteness as property; we have resisted, not accepted, the normativity of whiteness. Resistance, however, is taxing on mind, body, and spirit. As we tell our stories and speak our words, we heal ourselves and reclaim our humanity and knowledge about the world around us.

Maori intellectual Linda Tuhiwai Smith (1999) from Ngati Awa and Ngati Porou tribes reminds us of the power we have emanating from our cultures and ourselves as Indigenous Peoples.

To acquiesce is to lose ourselves entirely and implicitly agree with all that has been said about us. To resist is to retrench in the margins, retrieve what we were and remake ourselves. The past, our stories local and global, the present, our communities, cultures, languages, and social practices-all may be spaces of marginalization, but they have also become spaces of resistance and hope. (p. 4)

Our stories and words are, as well, offerings to non-Indigenous people so they may come to know and move into ally-ship with us for that needed transformative work. As Brayboy (2005) suggests, TribalCrit offers to nonIndigenous educators "a new and more culturally nuanced way of examining the lives and experiences of tribal peoples" (p. 430). Ladson-Billings and Tate (1995) assert that "the 'voice' component of critical race theory provides a way to communicate the experience and realities of the oppressed, a first step on the road to justice" (p. 58).

Whereas MCE, multiculturalism and the inclusion of Indigenous Peoples in educational contexts or content has been critiqued and connected to the continued process of colonization, I advocate for transformation and assert that 
we all have a responsibility to that transformation. Derrick Bell (2004) tells us that for racial justice to occur we must invest ourselves in "tactics, actions, and even attitudes that challenge the continuing assumptions of white dominance" (p. 9). To do that as, for, and with Indigenous Peoples, I maintain that educators must situate MCE as social justice. MCE as social justice, supported and informed by CRT and TribalCrit, transforms educational and societal structures by disrupting and countering colonization. As absences, silences, inaccurate representations, and static portrayals give way to Indigenous frames of reference--that is, what we have to say about ourselves through our stories and perspectives-colonization is unmasked, exposed, confronted, and transformed.

\section{Notes}

1. Terminology proved to be a challenging issue within this article-as it also proved to be at the Native American/Indigenous Studies meeting when discussing what to call our newly formed organization. Within this article I use the terms Indigenous and Indigenous Peoples to be inclusive of all groups. I use Native, Native American, and Native People, to be inclusive of Indigenous People in North America. It is important to make the distinction that most Indigenous Peoples prefer to use their specific tribal, group or homeland name rather than these collective terms.

2. Hermes (1999), in footnote 2 of her chapter, addresses the influential nature of CRT on her work but makes the important statement of acknowledging the influence of Ojibwe traditions and teachings on her work as well.

3. McDonald (2003) explained that while CRT has great potential to explore and transform the educational experiences of Aboriginal students it has not been grasped by Australian researchers.

4. The people group "whites" is written with the lower case letter " $w$ " throughout the text as is typical of Critical Race Theory literature.

5. In 2006, Pearce was confronted with circulating an article to supporters through e-mail from National Alliance, a white separatist group ("Arizona lawmaker circulated," 2006).

6. Whereas tribal governments are often said to have been abolished upon statehood, Conley (2005), Debo (1940/1991), and Mankiller and Wallis (1993) discuss their continuance in various forms after statehood.

\section{References}

Adams, D. W. (1995). Education for extinction: American Indians and the boarding school experience, 1875-1928. Lawrence, KS: University Press of Kansas. 
Archuleta, M. L., Child, B. J., \& Lomawaima, K. T. (2000). Away from home: American Indian boarding school experiences, 1879-2000. Phoenix, AZ: Heard Museum.

Arizona lawmaker circulated white separatist e-mail (2006, October 16). USA Today. Retrieved April 29, 2008, from http://www.usatoday.com/news/ nation/ 2006-10-12-race-supremacy x.htm

Arizona State Legislature (2008). Proposed House of Representatives amendments to S.B. 1108. Retrieved April 23, 2008, from http://www.azleg.gov/FormatDocument.asp?inDoc=/legtext/48leg/2R/prop osed/H.1108RP2.DOC.htm

Bell, D. A. (2004). Silent covenants: Brown v. Board of Education and the unfulfilled hopes for racial reform. New York: Oxford University Press.

Bell, D. A., Jr. (1980). Brown $v$ Board of education and the interest convergence dilemma. Harvard Law Review, 93, 518-533.

Bell, L. A. (1997). Theoretical foundations for social justice education. In M. Adams, L. A. Bell, \& P. Griffin (Eds.), Teaching for diversity and social justice: A sourcebook (pp. 1-15). New York: Routledge.

Brayboy, B. M. J. (2005). Toward a tribal critical race theory in education. The Urban Review, 37(5), 425-446.

Conley, R. J. (2005). The Cherokee Nation: A history. Albuquerque, NM: University of New Mexico Press.

Debo, A. (1940/1991). And still the waters run: A betrayal of the five civilized tribes. Princeton, NJ: Princeton University Press.

Delgado, R. (1989). Storytelling for oppositionists and others: A plea for narrative. Michigan Law Review, 87, 2411-2441.

Delgado, R., \& Stefancic, J. (2001). Critical race theory: An introduction. New York University Press.

Harris, C. (1993). Whiteness as property. Harvard Law Review, 106, 1701-1791.

Haynes Writer, J. (2002a). "No matter how bitter, horrible, or controversial": Exploring the value of a Native American education courses in a teacher education program. Action in Teacher Education, 24(2), 9-21.

Haynes Writer, J. (2002b). Terrorism in Native America: Interrogating the past, examining the present, and constructing a liberatory future. Anthropology \& Education Quarterly, 33(3), 317-330.

Haynes Writer, J. (2008, April). Imagin[ary]ing Oklahoma's centennial: Celebrating a grand event or a grand narrative. Presented at the Native American and Indigenous Studies Conference, Athens, GA.

Hermes, M. (1999). Research methods as a situated response: Toward a First Nations' methodology. In L. Parker, D. Deyhle, \& S. Villenas (Eds.), Race 
is...race isn't: Critical race theory and qualitative studies in education (pp. 83-100). Boulder, CO: Westview Press.

Hoxie, F. E. (1984). A final promise: The campaign to assimilate the Indians, 1880-1920. Lincoln, NE: University of Nebraska Press.

Kvasnicka, R. M., \& Viola, H. J. (1979). The commissioners of Indian affairs: 1824-1977. Lincoln, NE: University of Nebraska Press.

Ladson-Billings, G. (1998). Just what is critical race theory and what's it doing in a nice field like education? International Journal of Qualitative Studies in Education, 11(1), 7-24.

Ladson-Billings, G., \& Tate, W. F., IV. (1995). Toward a critical race theory of education. Teachers College Record, 97(1), 47-68.

Lomawaima, K. T. (1994). "You're a woman, you're going to be a wife." In They called it prairie light: The story of the Chilocco Indian school (pp. 81-100). Lincoln, NE: University of Nebraska Press.

Mankiller, W. (2003, February). Sovereignty protection: The challenges ahead. Paper presented at the Fourth Annual American Indian Studies Consortium, Arizona State University, Tempe, AZ.

Mankiller, W., \& Wallis, M. (1993). Mankiller: A chief and her people. New York: St. Martin's Press.

May, S. (Ed.). (1999). Critical multiculturalism: Rethinking multicultural and antiracist education. Philadelphia: Falmer Press.

McDonald, H. (2003). Exploring the possibilities through critical race theory: Exemplary pedagogical practices for Indigenous students. Paper prepared for the New Zealand ARE/AARE Joint Conference. Retrieved April 29, 2008, from http://www.aare.edu.au/03pap/mcd03504.pdf\#search=Critical \%20Race\%20Theory\%20Indigenous

McNutt, M. (2007). American Indians demonstrate: Some don't want revelry. Retrieved November 28, 2007, from http://newsok.com/article/3170420/ ?print=1

Mohawk, J. C. (2000). European expansion in North America. In Utopian legacies: A history of conquest and oppression in the western world (pp. 177-196). Santa Fe, NM: Clear Light Publishers.

Nieto, S., \& Bode, P. (2008). Affirming diversity: The sociopolitical context of multicultural education ( $5^{\text {th }}$ ed.). Boston: Allyn and Bacon.

Oakes, J., \& Lipton, M. (2007). Teaching to change the world ( $3^{\text {rd }}$ ed.). Boston: McGraw-Hill College.

Oklahoma Council for the Social Studies (n.d.). Centennial corner. Retrieved February 7, 2008, from http://www.okcss.org/centennial corner.htm

Pease-Windy Boy, J. (1995). Cultural diversity in higher education: An American Indian perspective. In C. E. Sleeter \& P. L. McLaren (Eds.), Multicultural 
education, critical pedagogy, and the politics of difference (pp. 399-413). Albany, NY: State University of New York Press.

Perdue, T. (2001). Catharine Brown: Cherokee convert to Christianity. In Sifters: Native American women's lives (pp. 77-91). New York: Oxford University Press.

Pewewardy, C. D. (1999). Culturally responsive teaching for American Indian students. In E. R. Hollins \& E. I. Oliver (Eds.), Pathways to success: Culturally responsive teaching (pp. 85-100). Mahwah, NJ: Lawrence Erlbaum Publishers.

Porter, R. O. (2005). The decolonization of Indigenous government. In W. A. Wilson \& M. Yellow Bird (Eds.), For Indigenous eyes only: A decolonization handbook (pp. 87-108). Santa Fe, NM: School of American Research Press.

Prucha, F.P. (Ed.). (2000). Documents of United States Indian policy. (3 ${ }^{\text {rd }}$ ed.). Lincoln, NE: University of Nebraska Press.

Rains, F. V. (2003). To greet the dawn with open eyes: American Indians, white privilege and the power of residual guilt in the social studies. In G. LadsonBillings (Ed.), Critical race theory perspectives on the social studies: The profession, policies, and curriculum (pp. 199-227). Greenwich, CT: Information Age Publishing.

Smith, L. T. (1999). Decolonizing methodologies: Research and Indigenous Peoples. Dunedin, New Zealand: University of Otago Press.

Solorzano, D., \& Yosso, T. (2002). Critical race methodology: Counterstorytelling as an analytical framework. Qualitative inquiry, 8(1), 23-44.

Spack, R. (2002). America's second tongue: American Indian education and the ownership of English, 1860-1900. Lincoln, NE: University of Nebraska Press.

Spring, J. H. (1996). The cultural transformation of a Native American Family and its Tribe, 1763-1995: A basket of apples (sociocultural, political, and historical studies in education). Mahwah, NJ: Lawrence Erlbaum Associates.

Stannard, D. E. (1992). American holocaust: Columbus and the conquest of the new world. New York: Oxford University Press.

Stiffarm, L. A., \& Lane, P., Jr. (1992). The demography of Native North America: A question of American Indian survival. In M. A. Jaimes, (Ed.), The state of Native America: Genocide, colonization, and resistance (pp. 23-53). Boston: South End Press.

Thornton, R. (1987). American Indian holocaust and survival; A population history since 1492. Norman, OK: University of Oklahoma Press. 
Trafzer, C. E., Keller, J. A., \& Sisquoc, L. (2006). Boarding school blues: Revisiting American Indian educational experiences. Lincoln, NE: University of Nebraska Press.

Williams, R. A. (1997). Vampires anonymous and critical race practice, 95 Mich. L. Rev. 741. Reprinted in R. Delgado and J. Stefancic (Eds.), (2001) Critical race theory: The cutting edge $\left(2^{\text {nd }}\right.$ ed.) (pp. 6-14). Philadelphia: Temple University Press.

Wilson, W. A., \& Yellow Bird, M. (Eds.). (2005). For Indigenous eyes only: A decolonization handbook. Santa Fe, NM: School of American Research Press.

Yellow Bird, M. (2005). Decolonizing tribal enrollment. In W. A. Wilson \& M. Yellow Bird (Eds.), For Indigenous eyes only: A decolonization handbook (pp. 179-188). Santa Fe, NM: School of American Research Press.

Young, I. M. (2000). Five faces of oppression. In M. Adams, W. J. Blumenfield, R. Castañeda, H. W. Hackman, M. L. Peters, \& X. Zúñiga (Eds.), Readings for diversity and social justice: An anthology on racism, antiSemitism, sexism, heterosexism, ableism, and classism (pp. 35-49). New York: Routledge. 